\title{
Entrepreneurial Potential of Students Graduating from Translation Studies
}

\begin{abstract}
Entrepreneurship is becoming a central issue in social, economic and educational policies globally. It is classified among the key assets that a contemporary university graduate needs to successfully enter the labour market - as an employee or a freelancer. Academic students who specialize in translation care about how their education translates onto their career. In this article, the authors present results of the research on how a selection of 436 Polish students of full-time translation courses perceive their future professional functioning in a hard and a soft-skill perspectives. The diagnostic procedure developed in the article can be of use to translation curricula designers and teachers in getting to know what their students think about being entrepreneurial translators. The data presented also show where educational interventions can be in place. A list of suggested didactic activities to exemplify such interventions is also provided.
\end{abstract}

\section{Key words}

entrepreneurship; translator education; lifelong learning; self-control; self-directedness; empowerment; emergent adulthood

\section{Introduction}

Due to the dynamic nature of civilization development, entrepreneurship can be described as one of the contemporary civilization needs. In its narrow sense, entrepreneurship has most often been related with business ventures and market competitive advantage (Davidsson 2008: 15-17). However, the notion has gradually been expanding in its meaning. Entrepreneurial mindset and attitudes, characteristics and competences are discussed today in a broad context of personal and social development. They are defined as resources for an efficient and creative functioning in society, regardless of whether an individual is formally an entrepreneur, and regardless of his/her educational profile.

The growing importance of entrepreneurship can be inferred from a number of documents, reports and research publications. For example, various EU-related institutions have issued a considerable body of documents showing its commitment to fostering innovation and entrepreneurship because of its role in contributing to "a successful life in a knowledge society" (European Parliament 2006: L.394/13). Most of these documents verbalise an expectation that European higher education institutions should take responsibility for delivering entrepreneurship-oriented education to their students (e.g. European Commission 2002, 2008, 2013, Bacigalupo et al. 2016).

Taking a more global look, one can refer to reports developed by analytical and consulting agencies, which explore the relationship between higher education and the market. For example, in two reports developed by McKinsey, the authors express a necessity for educational support for the growth of entrepreneurial resources in contemporary candidates to the labour market in Europe (Mourshed et al. 2014) and in the world (Mourshed et al. 2012). Analysing opinions of

* Katarzyna Klimkowska

Maria Curie Sklodowska University, Lublin

E-mail: katarzyna.klimkowska@poczta.umcs.lublin.pl
Konrad Klimkowski

John Paul II Catholic University of Lublin

E-mail: konrad.klimkowski@kul.pl 
numerous representatives of the labour market, the authors attempt to produce a diagnosis and a list of challenges that contemporary higher education needs to address. The OECD has also issued numerous reports in which entrepreneurship is directly addressed (see e.g. OECD 2017 - the latest among a series of reports starting back in 2013), while others approach the interdependence between education (including higher education) and the economic, social and cultural development of the world. These reports (e.g. the latest issue of OECD 2019) are intended to provide the public and the policy-makers with data and recommendations for actions intended to help the graduates make their lives more fruitful and successful in the individual and social perspective. For example, according to this latest report, over the past decade most OECD countries managed to increase access to education, yet this has not translated onto higher employability figures of young adults. In fact, "[i]n most of countries, increased access to education has been accompanied by a decreasing share of young adults in employment" (OECD 2019: 57).

The documents listed above fully justify the claim that education for entrepreneurship counts among objectives that should be pursued by higher education institutions. They are expected to provide education of highly specialized staff of the future, of graduates who can creatively adapt to a dynamic, changing labour market. In this context, entrepreneurship education needs to be understood as diverse actions taken in the academic space - from entrepreneurial (business-oriented) education of students up to support of students' entrepreneurial activity by universities (Binkauskas 2012, Osiri/McCarty 2013, Laukkanen 2003, Shattock 2005).

As regards higher education in Poland, the relevant research shows that the state institutions are aware of the importance of entrepreneurship education in preparing graduates of the future not only seeking their place on the market but ready to co-create an innovative market economy both as employees and self-employed persons. There are also reports available to prove that entrepreneurship education is present at Polish universities (e.g. OECD/EU 2017, Sadowska 2016, Jakubiak/Buchta 2016, Brzozowska et al. 2014, Wach 2002, 2013). Most often, this form of education is realised through dedicated academic subjects - compulsory or optional - included within educational curricula. For example, in 2018, The John Paul II Catholic University of Lublin launched a university-wide course in entrepreneurship, compulsory for all beginner students in virtually all the university faculties. ${ }^{1}$ Another form of supporting entrepreneurship by universities are business incubators or start-ups affiliated at Polish universities. ${ }^{2}$

Owing to the dynamic changes of the civilization and the market, successive generations of university graduates must display a wide spectrum of professional competences, particularly soft and entrepreneurial skills, for their transition from education to work to be successful. Hence, graduates should be able to successfully define their opportunities in the labour market, also in circumstances where job offers matching precisely their education profiles are not available.

One of the areas of professional activity in which entrepreneurial competences are highly significant is translation career. It is difficult to describe translation as a profession in the classical sense. It is rather a dynamic network of professional activities, with different levels and multiple facets of engagement (see the notion of translation competence discussed below). The complexity of the translation profession results both from the complexity of the translation act and from the way professional translation service provision is arranged. Since translators act as service providers, their dependence on entrepreneurial resources is unquestionable. This view is also advocated by Daniel Gouadec in his Translation as a Profession (Gouadec 2007). The book contains a detailed description of all types of processes and procedures that can be distinguished in all types of professional, market-oriented translation activities. Gouadec (2007) also describes the structure of the European translation market and its consequences for the current and future career prospects of translators.

1 Konrad Klimkowski is a co-author of the programme. Apart from regular classes and the final business project to complete, the subject includes two discussion panels with entrepreneurs in the Lublin region.

2 This can be exemplified by Inkubator innowacyjności: a collaborative project of Lublin Technical University, Maria Curie-Skłodowska University in Lublin and The John Paull II Catholic University of Lublin. 
The importance of entrepreneurial competence in the translation profession is also signalled in models of translation competence formulated in the literature in the field of translator education. The most frequently discussed models are:

a) by PACTE group (e.g. PACTE 2008)

b) by Göpferich (e.g. Göpferich 2009)

c) by EMT experts (EMT 2009)

PACTE group developed a model of translation competence and its acquisition in an on-going series of publications starting from 1997 and recently accumulatively discussed in what the editor claims to be 'a compendium' of PACTE's research legacy (Hurtado Albir 2017). Even though it displays a few differences, a model by Göpferich (2009) shares a lot with the PACTE's formulation: they both focus primarily on translation competence as a cognitive phenomenon and its acquisition as a learning and developmental process.

The EMT experts adopted a different approach to defining what a translator needs to know to perform effectively. EMT (2009) can be named an applied rather than truly theoretical model. This is evidenced by the fact that the central position in this conception is occupied by the translation service provision competence - in contrast to the strategic competence postulated in the two other models. A recent version of the competence framework developed by EMT (2017) gives the following introduction to a section dedicated to the translation service provision competence:

This competence covers all the skills relating to the implementation of translation and, more generally, to language services in a professional context - from client awareness and negotiation through to project management and quality assurance. (EMT 2017: 11)

This quotation perhaps suffices to justify the claim that the EMT $(2009,2017)$ formulations of translation competence relate most closely to the topic of entrepreneurial education of future translators.

The issue of translator entrepreneurship and entrepreneurial education has also been discussed in a growing number of research publications (e.g. Abdallah 2011, Koby 2013, Sidiropoulou 2017 or Vandepitte 2009) and perhaps an even larger number of profession guidebooks or reflections (e.g. Alianelli 2006, Durban 2010, Jenner/Jenner 2010, McKay 2017 or Whitty 2014). Notwithstanding the above, it is rather difficult to say that entrepreneurship belongs to the main current of the debate in translator education. Thus, apart from the research objectives specified below, there is also a more general one that the authors pose: to convince the reader that entrepreneurial skills deserve to be regarded as central for translator professional functioning and education. The more advanced the entrepreneurial assets of the students of translation, the greater the chance that their translation competence becomes real rather than remaining an educational holy grail.

\section{Research methodology and study group}

The specificity of the translation profession and the conditions that the Polish labour market sets for graduates of humanities have become an impulse for the authors to undertake research on the entrepreneurial resources of students graduating from translation studies. The presented research belongs to a series of empirical explorations of the specificity of the professional functioning of future translators, carried out by the authors of this study (Klimkowska 2013, 2014, Klimkowski 2015a, 2015b, Klimkowska/Klimkowski 2015).

As indicated above, entrepreneurship is approached in diverse ways in these research projects, with the aim of getting to know its various aspects or dimensions. The aim of the research reported in this article is to diagnose selected entrepreneurial resources of future translators and postulate enhancement measures. The main research objective consisted of two specific objectives:

getting to know the students' intentions as regards self-employment and self-assessment of their own entrepreneurial potential; 
- getting to know the level of the dimensions of students' entrepreneurial abilities - work engagement, success, practical competence, self-control and self-directedness.

For research purposes, the authors used the Entrepreneurial Aptitude Questionnaire developed by Noworol (2008, original Kwestionariusz Uzdolnien Przedsiębiorczych). This tool is in wide use in Poland in the area of career counselling and guidance. The authors have adopted an operational, general category of entrepreneurial resources, which consists of:

1. the dimensions of entrepreneurial aptitudes defined by Noworol (2008);

2. the students' individual aspirations for self-employment;

3. the students' beliefs about their own entrepreneurial qualities.

Noworol (2008) distinguished five dimensions of entrepreneurial aptitudes:

1. energy for work;

2. success;

3. practical competences;

4. $\quad$ self-control;

5. self-directedness.

The notion of 'energy for work' as defined by Noworol (2008: 5-6) refers to people who:

are highly motivated, open to new challenges, competitive, seeking recognition and prestige, and often have professional success. High energy to work is not cost-free. It is often associated with high impatience, high stress and many of its consequences.

Thus, 'energy for work ' seems closely related to intrinsic motivation, empowerment, feeling jobready etc. The success dimension refers to the need for personal achievement and is associated with features such as ambition and willingness to risk high costs in the personal sphere (Noworol 2008: 7). Practical competences are needed to perform tasks creatively and with extensive knowledge and expertise (acquired through learning also in a non-formal educational context) (Noworol 2008: 8). Self-control describes a person's disposition regarding emotional intelligence. Noworol (2008) considers this competence to be one of the leading successful entrepreneurial traits. Scoring high results in this dimension allows us to anticipate that the person has a 'good contact' with himself/herself, recognizes and understands the emotions he/she experiences, can also manage his/her reactions adequately to the situation and to the goal. As a result, he/she is effective in communicating and creating positive relationships with other people (Noworol 2008: 9). The last entrepreneurial construct distinguished in the discussed approach - self-directedness - is closely related to the notion of locus of control (Rotter 1966), i.e. to the personal belief concerning the scope of influence on one's own course of life (Noworol 2008: 10-11).

The research reported in this article was quantitative. It relied on diagnostic survey as its research methodology. It employed the above-mentioned Entrepreneurial Aptitudes Questionnaire by Noworol (2008) as a research tool. Additionally, the research used a questionnaire developed by the authors of the article, concerning socio-demographic data as well as students' entrepreneurial intentions and plans. The main research phase was proceeded by a pilot study ( 34 respondents) that allowed us to improve and customize the tool. The questionnaire was anonymous and was delivered in the paper form and filled in during classes or meetings of the teachers and students 
who agreed to participate. Students worked on the questionnaires individually, provided with a written instruction.

A call for participation was sent to 24 academic units (faculties, institutes or departments) that offered a form or translation specialization at 14 Polish universities: Adam Mickiewicz University in Poznań, University of Gdańsk, Jagiellonian University, The John Paul II Catholic University of Lublin, University of Łódź, Maria Curie-Skłodowska University in Lublin, University of Opole, University of Rzeszów, University of Szczecin, University of Silesia in Sosnowiec, University of Warsaw, University of Wrocław, Higher School of Philology in Wrocław and Higher School of Social Psychology in Warsaw.

Out of 24 units, 16 responded, yielding the total of 436 questionnaires for analysis. Taking into account that the number of collected responses was relatively low, the results cannot be regarded as representative for the researched population. Yet, even if not representative statistically, the batch of data collected offers a chance for a valuable generalization of results.

A decision to conduct research with students of the master's course was dictated by the fact that for the vast majority of students in Poland the second-cycle studies are the final stage of academic education. ${ }^{3}$ This group thus stands at the threshold of transition from education to work, and in this sense entrepreneurial potential is a more vital asset for them than for the first-cycle graduates. The main demographic and social characteristics of the researched students are presented in Table 1.

\begin{tabular}{|l|c|r|}
\hline Gender & $\mathbf{N}$ & $\mathbf{\%}$ \\
\hline a) Female & 355 & 81.42 \\
\hline b) Male & 81 & 18.58 \\
\hline Year of master's studies & $\mathrm{N}$ & $\%$ \\
\hline a) I year & 248 & 56.88 \\
\hline b) II year & 188 & 43.12 \\
\hline Foreign languages known at the translation level* & $\mathrm{N}$ & $\%$ \\
\hline a) English & 350 & 80.28 \\
\hline b) German & 118 & 27.06 \\
\hline c) French & 58 & 13.30 \\
\hline d) Spanish & 52 & 11.93 \\
\hline e) Russian & 38 & 8.72 \\
\hline f) Italian & 19 & 4.36 \\
\hline g) other languages (Portuguese, Czech, Belarusian, Bosnian, Croatian, Finnish, & 5 & 4.59 \\
\hline$\quad$ Japanese, Catalan, Norwegian, Romanian, Serbian, Swedish) & $\mathbf{N}$ & $\mathbf{\%}$ \\
\hline Number of foreign languages at translation level & 255 & 58.49 \\
\hline a) one language & 151 & 34.63 \\
\hline b) two languages & 25 & 5.73 \\
\hline c) three languages & 5 & 1.15 \\
\hline d) four languages and more & & \\
\hline
\end{tabular}

Table 1: The structure of the research group by selected demographic and educational features

3 The choice of MA students can be explained by the specificity of the BA/MA division in Poland. Unlike many academic systems, BA courses at Polish universities are scarcely designed to prepare for market functioning. They by and large result from a mere administrative cut made in the traditional 5-year MA programmes. BA has never become a credential recognized professionally in Poland - in the field of professional translation or otherwise. 
Source: own research. ${ }^{*}$ The data in the table do not add up to $100.0 \%$ due to multiple answers. Most of the respondents were women $(81.42 \%)$, which is specific for the humanities in Poland. The students of the first year prevailed in the research group (56.88\%). Most of the students specialized in English translation (80.28\%), while the second largest group specialized in German $(27.06 \%)$. More than half of the respondents specialized in translations from one foreign language. A large group (34.63\%) knew two foreign languages at the translation level. A more detailed specification of the researched group can be found in Klimkowska/Klimkowski (2015).

\section{Research results}

The first topic explored when diagnosing the entrepreneurial resources of future translators was the students' intentions and plans as regards form of employment. Table 2 displays how the researched students responded.

\begin{tabular}{|c|c|c|}
\hline Intentions and plans regarding the form of employment & $\mathbf{N}$ & $\%$ \\
\hline $\begin{array}{l}\text { 1. Running your own business (e.g. single-person translation freelancing; your } \\
\text { translation agency; running your own business in another industry, and translation as } \\
\text { an additional job) }\end{array}$ & 146 & 33.48 \\
\hline $\begin{array}{l}\text { 2. Employment in a translation agency or employment in another industry, and } \\
\text { translation work in addition to this }\end{array}$ & 208 & 47.71 \\
\hline 3. Lack of specific intentions or plans & 82 & 18.81 \\
\hline Total & 436 & 100.00 \\
\hline
\end{tabular}

Table 2: Students' intentions and plans regarding the form of employment and type of professional activity. Source: own research.

It was found that most of the surveyed academic youth (81.19\%) had specific intentions and plans concerning the type of professional activity and form of employment. Employment prevailed (47.41\%) over self-employment (33.48\%). Worth noting is that almost one fifth of the respondents had no specific intentions or plans relating to their interaction with the job market. This observation may be indicative of a need of a specific educational intervention. On the one hand, over a half of the surveyed group were students of the first year of MA studies, which means they still had one year to define their plans. On the other hand, the sooner they determine their professional goals, the easier the process of their transition to the labour market. Thanks to being knowledgeable about the available options, students with their employment strategy or plans can modify their pathways of competence development to match the preferred type of market functioning. Hence, it is this group of future graduates who can benefit most from entrepreneurship education. This is how they can gain knowledge about the mechanisms of the labour market, possible forms of employment, competences sought for by the employers or the facts and factors needed for establishing and effective running their own businesses. The need for academic entrepreneurial education is also confirmed by the research conducted by the authors on the same research pool of future translators regarding the assessment of the translation service provision competence, as defined by EMT (2009) (see Klimkowska/Klimkowski 2015: 173). The research showed that the respondents felt more confident in situations related to the realization of a translation job (translation as such) than in situations related to the service-related functioning as a professional translator (contacting clients, negotiating prices or conditions etc.) (Klimkowska/Klimkowski 2015: 173). The surveyed students' responses revealed that their translation service provision competence was developed at medium level during their translation classes. It can be assumed that the result obtained is satisfactory. However, given the globally prevalent freelance profile of the profession (see Kuznik 2010), translation courses can be expected to offer a holistic understanding of the 
professional role of a translator, including its legal (regulations and standards), business (strategy and management), employment (freelancing, in-housing or hybrid) and marketing (branding and personal branding) aspects. (see Klimkowska/Klimkowski 2015: 180-181).

Another component of the entrepreneurial assets of future translators are their entrepreneurial skills. Noworol's (2008) exposition of these traits has already been discussed. Table 3 shows how the researched students assessed their potential in the five dimensions postulated by Noworol (2008).

\begin{tabular}{|c|c|c|}
\hline Energy for work & $\mathbf{N}$ & $\%$ \\
\hline 1. lack of energy & 0 & 0.00 \\
\hline 2. low energy & 2 & 0.46 \\
\hline 3. average energy & 193 & 44.27 \\
\hline 4. high energy & 217 & 49.77 \\
\hline 5. very high energy & 24 & 5.50 \\
\hline Success & $\mathbf{N}$ & $\%$ \\
\hline 1. lack of desire for success & 2 & 0.46 \\
\hline 2. low desire for success & 37 & 8.49 \\
\hline 3. average desire for success & 281 & 64.45 \\
\hline 4. high desire for success & 114 & 26.15 \\
\hline 5. very high desire for success & 2 & 0.46 \\
\hline Practical competence & $\mathbf{N}$ & $\%$ \\
\hline 1. lack of practical competence & 0 & 0.00 \\
\hline 2. low practical competence & 1 & 0.23 \\
\hline 3. average practical competence & 93 & 21.33 \\
\hline 4. high level of practical competence & 243 & 55.73 \\
\hline 5. very high level of practical (expert) competence & 99 & 22.71 \\
\hline Self-control & $\mathbf{N}$ & $\%$ \\
\hline 1. very poor self-control & 0 & 0.00 \\
\hline 2 , poor self-control & 1 & 0.23 \\
\hline 3. average self-control & 69 & 15.82 \\
\hline 4. above-average self-control & 260 & 59.63 \\
\hline 5. strong self-control & 97 & 22.28 \\
\hline 6. very strong self-control & 9 & 2.06 \\
\hline Self-directedness & $\mathbf{N}$ & $\%$ \\
\hline 1. very strong external control & 0 & 0.00 \\
\hline 2. dominant external control & 1 & 0.23 \\
\hline 3. both external control and self-directedness & 166 & 38.07 \\
\hline 4. dominant self-directedness & 266 & 61.01 \\
\hline 5. very high self-directedness & 3 & 0.69 \\
\hline
\end{tabular}

Table 3. Dimensions of entrepreneurial aptitudes of the surveyed students. Source: own research.

The distribution of results in Table 3 shows that three out of five dimensions distinguished by Noworol (2008) proved to be a strong entrepreneurial resource of the researched future translators: high 'energy for work', dominant self-directedness and expert practical competences. In the case of 'energy for work', $49.77 \%$ of respondents achieved a high result, which is optimal for successful entrepreneurial functioning. As noted above, people scoring high in this dimension are usual- 
ly highly motivated and are able to maintain their motivation. In addition, their focus on action is also reflected in their openness to new challenges. Therefore, these subjective characteristics are significant not only in the context of the students' entrepreneurial potential, but also of their overall career and life success.

It is worth noting, however, that only a minimally smaller group of students $(44.25 \%)$ assessed their 'energy for work' as average. It can be anticipated that in the case of almost one out of two future translators the level of energy available for work may not be a sufficient driving force for their effective entrepreneurial performance. Again, this - relatively large - group of students suggests a need for a relevant educational intervention. Contemporary learning approaches to translator education - based on constructivist (see Kiraly 2000, González Davies 2004) or emergentist (Kiraly 2013) view of learning - can come to aid in matters like intrinsic motivation control, student engagement, self-regulation etc. Of particular use here can be translation projects as a methodology that has the capability of transforming the translation classroom into a virtual translation agency (Thelen 2019).

Practical competences turned out to be the second most significant entrepreneurial resource of the respondents. Most of the students scored at the high and even the expert level $(55.73 \%+$ $22.71 \%)$. An observed distribution of results may indicate that the researched future translators were aware of their practical competences, which may augur well for their search of a preferred job or for pursuing a freelance career. Moreover, the majority of the surveyed students said that they undertook numerous activities to gain the widest possible experience and skill base before their fully-fledged entry on the market: taking up various forms of part-time employment, student practice, internships, non-formal or extracurricular profession-related projects (see Klimkowska 2013: 290). As explained by Noworol (2008: 8), employees with a high level of practical skills are appreciated for their professional versatility and ability to cope with different, sometimes very complex professional circumstances. This is demonstrated by the diversity of forms of employment and professions in which the researched future translators and interpreters worked during their studies. About two thirds of the respondents admitted that they earned their living, most often doing casual work. The professional experience of the already working students was generally unrelated directly to translation. The respondents most often took up employment as foreign language teachers, worked in trade and services, culture, tourism and did office work (Klimkowska 2013: 226-227).

The entrepreneurial resources of most of the students also included the intrinsic locus of control, with $61.01 \%$ of respondents achieving high results in this dimension. Strong self-directedness is associated with a strong conviction of having influence on one's own life and a high sense of autonomy. This dominance also means adaptive flexibility, expressed, among other things, in a planned response to the situational impact of extrinsic control factors (e.g. client's pressure on price discounts). A self-directed person is very likely to utilize highly efficient mechanisms of creative adaptation (in contrast to passive compliance) to new or challenging situations. As a freelancer, a translator needs to adapt, but remain autonomous and keep the ability to take responsible decisions.

The dimensions that represent the weakest entrepreneurial capital of the researched students are success and self-control. Both result scales were dominated by average and above-average results. The results reached respectively $64.45 \%$ for the average, and $26.15 \%$ for the high desire for success. As for self-control, $59.63 \%$ of the respondents scored as average, while $22.28 \%$ as above average. The analysis of these dimensions allows anticipating that an average desire for success may translate into moderate professional achievements; yet it is not bound to hinder the professional functioning of a translator. Conversely, low levels of self-control are bound to have a much greater impact on professional success. Translation is, as indicated above, a service provision activity, and is inseparably connected with a need for effective communication and extensive contact with the client. Self-control, according to Noworol (2008: 9), relates directly to emotional intelligence, and seems to have a significant impact on the quality of any project involving human in- 
teraction. As emphasised by this researcher, people with a high level of self-control usually exhibit advanced abilities to comprehend the emotions they experience and control their expression. Hence, they can communicate effectively and shape positive, satisfying relations with other people. Moreover, they often demonstrate managerial skills, including the ability to create favourable conditions for teamwork (Noworol 2008: 9).

It is worth emphasising that self-control is an important resource not only in relation to entrepreneurial involvement, but is a key attribute of adulthood. The average and above-average results recorded in the research on this dimension can be analysed from the point of view of the developmental age of the students. Adopting a viewpoint developed by Arnett (Tanner et al. 2009), the researched students are going through a developmental stage he names emerging adulthood (rather than the classically evoked stage of early adulthood, see e.g. Erikson 1968 or Havighurst 1972). Arnett decided to distinguish this development stage as he observed that contemporary youth about the age of twenty hardly ever undertake the full spectrum of social activities attributed to adulthood. According to Arnett, emerging adulthood is a time of "identity explorations, of instability, of the self-focus, of feeling in-between and of possibilities" (Tanner et al. 2009: 342). Experimenting with various life choices, including professional ones, allows emerging adults to accumulate their capital of experience leading to the crystallization of adult identity and to the strengthening of one's beliefs about the preferred future. The results displayed by the future translators as regards self-control can be treated as a positive forecast of their entrepreneurial resources.

Categorising the research results by gender exhibits differences between how female and male students assessed their entrepreneurial aptitudes. The results are displayed in Table 4.

\begin{tabular}{|c|c|c|c|c|c|c|c|}
\hline & \multirow[b]{2}{*}{ M } & \multicolumn{5}{|c|}{ Dimensions of entrepreneurial aptitudes } & \multirow{2}{*}{$\begin{array}{c}\text { Mann-Whitney's } \\
\text { test }\end{array}$} \\
\hline & & Me & Min & Max & SD & & \\
\hline \multicolumn{7}{|c|}{ Energy for work } & \\
\hline \multirow[t]{14}{*}{ Gender } & Women & 28.10 & 28 & 18 & 39 & 3.43 & $Z=1.395$ \\
\hline & Men & 27.36 & 27 & 19 & 37 & 3.87 & $\mathrm{p}=0.163$ \\
\hline & \multicolumn{7}{|c|}{ Success } \\
\hline & Women & 25.15 & 25 & 12 & 35 & 3.54 & \multirow{2}{*}{$\begin{array}{l}\mathrm{Z}=-2.008 \\
\mathrm{p}=0.044^{*}\end{array}$} \\
\hline & Men & 26.00 & 27 & 18 & 34 & 3.89 & \\
\hline & \multicolumn{7}{|c|}{ Practical competence } \\
\hline & Women & 32.25 & 32 & 21 & 42 & 3.74 & \multirow{2}{*}{$\begin{array}{l}\mathrm{Z}=-2.952 \\
\mathrm{p}=0.003^{*}\end{array}$} \\
\hline & Men & 33.64 & 34 & 27 & 41 & 3.54 & \\
\hline & \multicolumn{7}{|c|}{ Self-control } \\
\hline & Women & 54.61 & 55 & 23 & 75 & 7.21 & \multirow{2}{*}{$\begin{array}{l}Z=0.567 \\
p=0.570\end{array}$} \\
\hline & Men & 54.31 & 53 & 37 & 73 & 7.07 & \\
\hline & \multicolumn{7}{|c|}{ Self-directedness } \\
\hline & Women & 34.49 & 34 & 24 & 46 & 3.62 & \multirow{2}{*}{$\begin{array}{c}Z=-1.568 \\
p=0.117\end{array}$} \\
\hline & Men & 35.48 & 35 & 25 & 49 & 4.56 & \\
\hline
\end{tabular}

Table 4: Gender differentiation in entrepreneurial qualities of future translators. Source: own research. * statistically significant at $\mathrm{p}<0.050$.

The results show that women and men differ significantly in terms of such dimensions of entrepreneurial abilities as success $(p=0.044)$ and practical skills $(p=0.003)$. In both cases, men scored higher than women. The recorded differences seem to corroborate observations made in relevant studies in Poland (e.g. Bombiak 2016, Gromkowska-Melosik 2011 or Pufal-Struzik 2017) and abroad (Hesmondhalgh/Baker 2015, Hüttges/Fay 2015 or Yung/Takeuchi 2016), concerning gender 
differentiation - often caused by social and stereotypical factors - as regards entrepreneurial and career resources and the related self-perception.

Irrespective of a presumably complex matrix of factors that influence the weaker results of the female students presented in Table 4, the disparity between their scores and the ones by the males constitutes a reason for an education intervention. The previously mentioned courses or classes in entrepreneurship should define an educational objective of transforming the stereotypically socially constructed roles for women to empower their entrepreneurial potential, without ignoring their right for functioning distinctly from men as successful entrepreneurs.

The last task to be achieved in the discussed analyses was to determine the relationship between the entrepreneurial aptitudes of the researched translation students and their intentions or plans to start their own businesses. The results are displayed in Table 5.

\begin{tabular}{|c|c|c|c|c|c|c|c|}
\hline & \multirow[b]{2}{*}{$\mathbf{M}$} & \multicolumn{5}{|c|}{ Dimensions of entrepreneurial capacities } & \multirow{2}{*}{$\begin{array}{c}\text { ANOVA variance } \\
\text { analysis (including } \\
\text { post-hoc test: Tukey's } \\
\text { RIR) }\end{array}$} \\
\hline & & Me & Min & Max & SD & & \\
\hline \multicolumn{7}{|c|}{ Energy for work } & \\
\hline \multirow{19}{*}{$\begin{array}{c}\text { Intentions } \\
\text { to set up } \\
\text { a business } \\
\text { of one's } \\
\text { own }\end{array}$} & Intends to (I) & 28.37 & 29 & 20 & 39 & 3.70 & \multirow{3}{*}{$\begin{array}{l}F=1.579 \\
p=0.207\end{array}$} \\
\hline & $\begin{array}{l}\text { Does not intend } \\
\text { to (II) }\end{array}$ & 27.81 & 28 & 18 & 36 & 3.50 & \\
\hline & $\begin{array}{l}\text { Does not know } \\
\text { (III) }\end{array}$ & 27.61 & 27 & 19 & 34 & 3.21 & \\
\hline & \multicolumn{7}{|c|}{ Success } \\
\hline & Intends to (I) & 26.18 & 26 & 17 & 33 & 3.53 & \\
\hline & $\begin{array}{l}\text { Does not intend } \\
\text { to (II) }\end{array}$ & 25.10 & 25 & 16 & 35 & 3.36 & $\begin{array}{c}\mathrm{F}=8.203 \\
\mathrm{p}=0.000^{*}\end{array}$ \\
\hline & $\begin{array}{l}\text { Does not know } \\
\text { (III) }\end{array}$ & 24.28 & 24 & 12 & 33 & 4.08 & I-II and I-III) \\
\hline & \multicolumn{7}{|c|}{ Practical competence } \\
\hline & Intends to (I) & 32.88 & 33 & 21 & 41 & 3.78 & \multirow{3}{*}{$\begin{array}{l}F=1.537 \\
p=0.216\end{array}$} \\
\hline & $\begin{array}{l}\text { Does not intend } \\
\text { to (II) }\end{array}$ & 32.45 & 32 & 24 & 42 & 3.65 & \\
\hline & $\begin{array}{l}\text { Does not know } \\
\text { (III) }\end{array}$ & 31.99 & 32 & 22 & 41 & 3.85 & \\
\hline & \multicolumn{7}{|c|}{ Self-control } \\
\hline & Intends to (I) & 55.87 & 56 & 37 & 73 & 7.05 & \multirow{3}{*}{$\begin{array}{c}\mathrm{F}=4.138 \\
\mathrm{p}=0.016^{*} \\
\text { (difference between } \\
\text { I-III) }\end{array}$} \\
\hline & $\begin{array}{c}\text { Does not intend } \\
\text { to (II) } \\
\end{array}$ & 54.13 & 54 & 36 & 71 & 6.87 & \\
\hline & $\begin{array}{l}\text { Does not know } \\
\text { (III) }\end{array}$ & 53.29 & 54 & 23 & 75 & 7.85 & \\
\hline & \multicolumn{7}{|c|}{ Self-directedness } \\
\hline & Intends to (I) & 35.58 & 35 & 25 & 49 & 4.20 & \multirow{3}{*}{$\begin{array}{c}\mathrm{F}=7.278 \\
\mathrm{p}=0.001^{*} \\
\text { (difference between } \\
\text { I-II and I-III) }\end{array}$} \\
\hline & $\begin{array}{l}\text { Does not intend } \\
\text { to (II) }\end{array}$ & 34.40 & 34 & 24 & 46 & 3.46 & \\
\hline & $\begin{array}{l}\text { Does not know } \\
\text { (III) }\end{array}$ & 33.74 & 34 & 25 & 42 & 3.73 & \\
\hline
\end{tabular}

Table 5: Entrepreneurial capacities and entrepreneurial intentions of future translators. Source: own research. ${ }^{*}$ statistically significant at $\mathrm{p}<0.050$. 
Statistical analysis revealed that the entrepreneurial intentions and plans of the researched future translators significantly differentiate the levels of the three dimensions of entrepreneurial aptitudes: success $(p=0.000)$, self-control $(p=0.016)$ and self-directedness $(p=0.001)$. In all the three dimensions, the highest results were achieved by the students who declared their willingness to start their own business. In the case of the success and the self-directedness dimension, statistically significant differences were discovered between the students intending and not intending to engage in entrepreneurial activity as well as between the students intending to become self-employed and those who were unable to declare their professional plans. As regards self-control, statistically significant differences were found between the declared entrepreneurs and the hesitant group.

The recorded differences indicate that students with business plans achieved the highest results in all the dimensions of entrepreneurial aptitudes, including those where the differences were not statistically significant. Although determining the direction of differentiation was not among the objectives that these analyses pursued, the obtained results lead to the conclusion about a feedback loop between entrepreneurial aptitudes and the willingness to start a business of one's own. On the one hand, it seems justifiable to assume that the more developed the entrepreneurial aptitudes of the students, the more open they are to the perspective of starting their own business. On the other, the very desire to be an entrepreneur may stimulate a person to take actions aimed at developing their resources necessary for effective entrepreneurial performance. Therefore, regardless of the preferred direction of the anticipated dependencies, the discovered relationship of entrepreneurial talents and intentions revealed in the research has a high practical value. It may be the basis for constructing implications for broadly understood entrepreneurship education.

\section{Educational recommendations and conclusions}

As a way of complementing the picture unveiled by the research discussed in this article, the authors would like to formulate a handful of didactic recommendations that can help carry out the educational interventions postulated throughout this article. 


\begin{tabular}{|c|c|c|}
\hline $\begin{array}{l}\text { Recommendations for translator } \\
\text { education }\end{array}$ & Explanation & Suggested activities \\
\hline $\begin{array}{l}\text { Training on types of interaction } \\
\text { with the market (employment, } \\
\text { freelancing, hybrid), including legal, } \\
\text { administrative and tax regulations } \\
\text { of entrepreneurial functioning and } \\
\text { employment }\end{array}$ & $\begin{array}{l}\text { Data shows that many the researched } \\
\text { students find it troublesome to } \\
\text { determine how they plan to interact } \\
\text { with the market. }\end{array}$ & $\begin{array}{l}\text { - students' research on types of } \\
\text { interaction (from documents, } \\
\text { websites and contacts) } \\
\text { - a Design Thinking workshop on } \\
\text { innovative types of freelancing/ } \\
\text { employment }\end{array}$ \\
\hline $\begin{array}{l}\text { Training in business strategy and } \\
\text { management }\end{array}$ & $\begin{array}{l}\text { Students can benefit from better } \\
\text { comprehending the translation } \\
\text { business reality, its flexibilities } \\
\text { and constraints. They can learn } \\
\text { strategic thinking and managing } \\
\text { even the simplest forms of market } \\
\text { engagement. This can have an } \\
\text { empowering effect: growth of energy } \\
\text { (motivation) and self-esteem (desire } \\
\text { for success). }\end{array}$ & $\begin{array}{l}\text { - case studies of different translation } \\
\text { businesses } \\
\text { - a project: my translation business } \\
\text { (SWOT analysis, mission, vision, } \\
\text { processes and product/service } \\
\text { range, pricing) }\end{array}$ \\
\hline $\begin{array}{l}\text { Training in marketing and personal } \\
\text { branding }\end{array}$ & $\begin{array}{l}\text { Developing tools of consistent } \\
\text { communication with clients } \\
\text { (negotiations, new or expanded } \\
\text { offers). Of importance is the } \\
\text { disproportion between the female and } \\
\text { male students reported in the data, } \\
\text { showing the need for more efficient } \\
\text { methods of building female students' } \\
\text { awareness of their potential }\end{array}$ & $\begin{array}{l}\text { - workshop: what do I want my } \\
\text { clients to know and how to make } \\
\text { them know it? (choosing content, } \\
\text { channel, defining expected } \\
\text { response etc.) } \\
\text { - project: designing one's own } \\
\text { e-marketing portfolio (independent } \\
\text { website, FB/LinkedIn etc.) }\end{array}$ \\
\hline
\end{tabular}

Table 6. Recommendations for educational intervention in the field of translator entrepreneurship

The results of the research of the entrepreneurial potential of the group of 436 Polish students of translation show an extensive need for both debate and educational practice relating to the issue of entrepreneurship of translation trainees. In the opinion of the authors, the need significantly exceeds entrepreneurial education understood as making graduates ready to start their businesses. Perhaps the most synthetic way to present the conception of entrepreneurship advocated by the authors is to say that educational programmes need to facilitate students transgression into ecological adulthood: characterized by high competence in making life choices (professional and nonprofessional) that enable harmonious development of the person in its social and cultural context and consequently the pursuit of his/her autonomous career paths. In its wide meaning, entrepreneurship fits as a key value of Lifelong Learning and its four pillars: learning to be, to know, to do and to be together. Yet perhaps a more basic need that the research discloses is for diagnosing the entrepreneurial potential of any group of translation students. The research discussed here can be used as reference in constructing dedicated diagnostic questionnaires. These can help design educational activities - like the ones outlined briefly in Table 6 above - to empower students on their way to sustainable professional success.

\section{References}

Abdallah, Kristiina 2011: Towards Empowerment: Students' Ethical Reflection on Translating in Production Networks. In The Interpreter and Translator Trainer 5(1), 129-154.

Alianelli, Martin 2006: The Entrepreneurial Translator. The ATA Chronicle 35 (2) [online]. http://www.alianelli.net/ atachroniclearticle.html (accessed 10 May 2019) 
Bacigalupo, Margherita/Kampylis, Panagiotis/Punie, Yves/Van den Brande, Godelieve 2016, EntreComp: The Entrepreneurship Competence Framework. Brussels: Joint Research Centre, European Commission.

Binkauskas, Gintaras 2012: Academic Entrepreneurship: Barriers and Fears versus Wishes and Opportunities. In International Journal of Technology Management and Sustainable Development 11(3), 231-244.

Bombiak, Edyta 2016: Płeć jako wyznacznik kariery zawodowej - mit czy rzeczywistość? In Marketing i Rynek 7, 53-71.

Brzozowska, Agnieszka/Glinka, Beata/Postuła, Agnieszka 2014: Role of University in Creating Entrepreneurial Attitudes. In Horyzonty Wychowania 13(26), 51-72.

Davidsson, Per 2008: The Entrepreneurship Research Challenge. Cheltenham/Northampton (MA): Edward Elgar.

Durban, Chris (ed.) 2010: The Prosperous Translator. Advice from Fire Ant and Worker Bee. Raleigh (NC): FA\&WB Press.

Erikson, Erik H. 1968: Identity, Youth and Crisis. New York/London: W.W. Norton.

European Commission/Enterprise Directorate-General 2002: Best Procedure: Project on Education and Training for Entrepreneurship. Brussels: European Commission.

European Commission 2008: Entrepreneurship in Higher Education, Especially with Non-Business Studies, Final Report of the Expert Group, European Commission - Enterprise and Industry Directorate-General, Brussels: European Commission.

European Commission 2013: Entrepreneurship 2020 Action Plan: Reigniting the Entrepreneurial Spirit in Europe. Brussels: European Commission.

European Parliament 2006: Recommendation of the European Parliament and of the Council of 18 December 2006 on Key Competences for Lifelong Learning. Official Journal of the European Union (2006/962/EC).

EMT 2009: Competences for Professional Translators, Experts in Multilingual and Multimedia Communication. Brussels: European Commission. [online] www.ec.europa.eu/dgs/ translation/programmes/emt/key_documents/emt_ competences_translators_en.pdf (accessed 28 May 2015)

EMT 2017: European Master's in Translation. Competence Framework 2017. Brussels, European Commission [online] https://ec.europa.eu/info/sites/info/files/emt_competence_fwk_2017_en_web.pdf (accessed 10 May 2019)

González Davies, Maria 2004: Multiple Voices in the Translation Classroom: Activities, Tasks and Projects. Amsterdam/Philadelphia: John Benjamins.

Gouadec, Daniel 2007: Translation as a Profession. Amsterdam/Philadelphia: John Benjamins.

Göpferich, Susanne 2009: Towards a Model of Translational Competence and its Acquisition: The Longitudinal Study TransComp. In Göpferich, Susanne/Jakobsen, Arnt L./ Mees, Inger M. (eds.), Behind the Mind. Methods, Models and Results in Translation Process Research. Copenhagen: Samfundslitteratur (Copenhagen Studies in Language 37), 11-37.

Gromkowska-Melosik, Agnieszka 2011: Edukacja i (nie) równość społeczna kobiet. Studium dynamiki dostępu. Kraków: Impuls.

Havighurst, Robert J. 1972: Developmental Tasks and Education. New York: McKay.

Hesmondhalgh, David/Baker, Sara 2015: Sex, gender and work segregation in the cultural industries. InThe Sociological Review 63(1), 23-36.

Hurtado Albir, Amparo 2017: Researching Translation Competence by PACTE Group. Amsterdam/New York: John Benjamins.

Hüttges, Annett/Fay, Doris 2015: Gender Influences on Career Development: A Brief Review. In Journal of Personnel Psychology 14(3), 113-120.

Jakubiak, Monika/Buchta, Krystyna 2016: Determinants of Entrepreneurial Attitudes in Relation to Students of Economics and Non-Economics. In Studia i Materiaty 2(21), 17-30.

Jenner, Judy A./Jenner, Dagmar V. 2010: The Entrepreneurial Linguist: The Business-School Approach to Freelance Translation. Las Vegas: EL Press.

Jung, Yuhee/Takeuchi, Norihiko 2016: Gender differences in career planning and success. In Journal of Managerial Psychology 31(2), 603-623.

Kiraly, Donald C. 2013: Towards a View of Translator Competence as an Emergent Phenomenon: Thinking Outside the Box(es) in Translator Education. In Kiraly, Donald C./Hansen-Schirra, Silvia/ Maksymski, Karin (eds.), New Prospects and Perspectives for Educating Language Mediators. Tübingen, Gunter Narr, 197-223.

Kiraly, Donald C. 2000: A Social Constructivist Approach to Translator Education. Empowerment from Theory to Practice. Manchester: St. Jerome Publishing. 
Klimkowska, Katarzyna/Klimkowski, Konrad 2015: Ksztattowanie kompetencji świadczenia ustug tlumaczeniowych z perspektywy przyszłych tlumaczy. Lublin: UMCS.

Klimkowska, Katarzyna 2014: Entrepreneurial Potential of the Students of Applied Linguistics Programme Majoring in Translation. In Academic Journal of Modern Philology 3, 18-26.

Klimkowska, Katarzyna 2013: Orientation on Professional Success of Students Graduating from Translation Studies. Lublin: UMCS.

Klimkowski, Konrad 2015a: Towards a Shared Curriculum in Translator and Interpreter Education, Wrocław, Washington D.C.: WSF.

Klimkowski, Konrad 2015b: Language Specialist as an Entrepreneur. In Sowa, Magdalena/Mocarz-Kleindienst, Maria/ Czyżewska, Urszula (eds.) Teaching Foreign Languages for the Needs of the Labour Market, Lublin: KUL, 163174.

Koby, Geoffrey S. 2013: Commercial Translation. In Chapelle, Carol A. (ed.), The Encyclopedia of Applied Linguistics. Oxford: Blackwell, 866-870.

Kuznik, Anna 2010: El contenido de los puestos de trabajo de los traductores. El caso de los traductores internos en las empresas de traducción de Barcelona. Ph.D. dissertation. Bellaterra: Universitat Autònoma de Barcelona

Laukkanen, Mauri 2003: Exploring Academic entrepreneurship: Drivers and Tensions of University-based Business. In Journal of Small Business and Enterprise Development 10(4), 372-382.

Mandal, Eugenia 2000: Podmiotowe i interpersonalne konsekwencje stereotypów związanych z płcią. Katowice: Uniwersytet Śląski.

Mourshed, Mona/Patel, Jigar/Suder, Katrin 2014: Education to Employment: Getting Europe's Youth into Work. McKinsey and Company. [online] http://mckinseyonsociety.com/education-to-employment/report/ ED (accessed 28 October 2015)

Mourshed, Mona/Patel, Jigar/Suder, Katrin 2012: Education to Employment: Designing a System that Works. McKinsey and Company. [online] http://mckinseyonsociety.com/education-to-employment/report/ (accessed 28 October 2015)

McKay, Corinne 2017: Finding and Marketing to Translation Agencies. A Practical Guide for Freelance Translators. No placename: Translatewrite.

Noworol, Czesław 2008: Kwestionariusz Uzdolnień Przedsiębiorczych KUP. Podręcznik dla doradców zawodowych. Kraków: Narodowe Forum Doradztwa Kariery.

OECD 2019: Education at a Glance 2019: OECD Indicators. Paris: OECD Publishing.

OECD 2017: Entrepreneurship at a Glance 2017. Paris: OECD Publishing.

OECD/EU 2017: Supporting Entrepreneurship and Innovation in Higher Education in Poland. Paris/Brussels: OECD Publishing/EU.

Osiri, John K./McCarty, Margaret M. 2013: Entrepreneurial Culture in Institutions of Higher Education: Impact on Academic Entrepreneurship. In Journal of Entrepreneurship Education 16, Special Issue, 4-11.

PACTE 2008: First Results of a Translation Competence Experiment: 'Knowledge of Translation' and 'Efficacy of the Translation Process'. In Kearns, John (ed.), Translator and Interpreter Training. Issues, Methods and Debates. London/New York: Continuum, 104-126.

Pufal-Struzik, Irena 2017: Aktywność zawodowa współczesnych kobiet - trudności w realizacji nowych ról i tradycyjnych obowiązków. In Polskie Forum Psychologiczne 22(2), 242-257.

Rotter, Julian B. 1966: Generalized Expectancies for Internal versus External Control of Reinforcement. In Psychological Monographs: General \& Applied 80(1), 1-28.

Sadowska, Monika 2016: Edukacja w zakresie przedsiębiorczości w polskim systemie kształcenia oraz w państwach europejskich. In Kosała, Małgorzata/Urbaniec, Maria/Żur, Agnieszka (eds.), Współczesne dylematy badań nad przedsiębiorczościa. Przedsiębiorczość Międzynarodowa 92(1), 149-164.

Shattock, Michael 2005: European Universities for Entrepreneurship: Their Role in the Europe of Knowledge. The Theoretical Context. In Higher Education Management and Policy 17(3), 13-25.

Sidiropoulou, Maria 2017: Markets and the Creative Paradigm: Identity Variability in English-Greek Translated Promotional Material. In JoSTrans - Journal of Specialized Translation 29, 102-125.

Tanner, Jennifer L./Arnett, Jeffrey J./ Leis, Julie A. 2009: Emerging Adulthood: Learning and Developing during the First Stage of Adulthood. In Smith, Cecil M./ DeFrates-Densch, Nancy (eds.), Handbook of Research on Adult Development and Learning, New York/London: Routledge, 34-67. 
Thelen, Marcel 2019: Quality and Quality Assessment in Translation: Paradigms in Perspective. In Huertas-Barros, Elsa/Vandepitte, Sonia/Iglesias-Fernandez, Emilia (eds.), Quality Assurance and Assessment Practices in Translation and Interpreting. Hershey PA: IGI Global, 1-25.

Vandepitte, Sonia 2009: Entrepreneurial Competences in Translation Training. In Kemble, Ian (ed.), The Changing Face of Translation. Proceedings of the 8th Portsmouth Translation Conference 2008. [online] Portsmouth http:// www.port.ac.uk/translation/events/translation-conference-2008/ (accessed 10 May 2019), 120-130.

Wach, Krzysztof 2013: Edukacja na rzecz przedsiębiorczości wobec współczesnych wyzwań cywilizacyjno-gospodarczych In Przedsiębiorczość - Edukacja (9), 246-257.

Wach, Krzysztof 2002: Szkoły wyższe w stużbie dla rozwoju przedsiębiorczości lokalnej. (Prace Naukowe Akademii Ekonomicznej we Wrocławiu 95). Wrocław: Akademia Ekonomiczna.

Whitty, Tess 2014: Marketing Cookbook for Translators: Foolproof Recipes for a Successful Freelance Career. No placename: CreateSpace. 